\title{
Free Trade Agreement with the European Union and food sovereignty in Ecuador: A review from the Economic Analysis of Law
}

\author{
Tratado de Libre Comercio con la Unión Europea y \\ soberanía alimentaria en Ecuador: Una mirada desde \\ el Análisis Económico del Derecho
}

\author{
Antonella Paredes Torres \\ Attorney at law and independent researcher \\ City: Quito \\ Country: Ecuador \\ Original article (research) \\ RFJ, No. 8, Vol I, 2020, pp. 167-191, ISSN 2588-0837
}

\begin{abstract}
This research article analyzes the current situation of food sovereignty in Ecuador linked with the Free Trade Agreement between Ecuador, Peru Colombia and the European Union (FTA), after almost four years of its entry into force, considering the impacts of the sanitary and economic crisis generated by the coronavirus pandemic in Ecuador, which has produced significant consequences for small food producers, specially in terms of poverty and inequality. In addition, this article aims to present a review of the implications that the Free Trade Agreement has had on the food sovereignty regime in Ecuador, from the economic analysis of law, analyzing whether this international instrument reduces transaction costs and is efficient in terms of food sovereignty, or whether an inalienability rule should be applied to counteract the externalities it generates in sustainable food production aligned with food sovereignty ${ }^{1}$.
\end{abstract}

KEYWORDS: international treaty, trade, right to food, market economy, agriculture.

RESUMEN: Este artículo analiza la situación actual de la soberanía alimentaria en Ecuador relacionada con el Tratado de Libre Comercio entre Ecuador, Perú Colombia y la Unión

1 This article is part of an independent research project whose main result will be a book focused on the analysis of Food Sovereignty in Ecuador. 
Europea (TLC), después de casi cuatro años de su entrada en vigor, considerando los impactos de la crisis sanitaria y económica generada por la pandemia del coronavirus en el Ecuador, misma que ha desencadenado consecuencias importantes para los pequeños productores de alimentos, especialmente en términos de pobreza y desigualdad. Además, este artículo pretende realizar una revisión de las implicaciones que el TLC ha tenido en el régimen de soberanía alimentaria en Ecuador, a partir del análisis económico del derecho, analizando si este instrumento internacional reduce costos de transacción y resulta eficiente en términos de soberanía alimentaria, o si se debería aplicar una regla de inalienabilidad para contrarrestar las externalidades que genera en la producción sostenible de alimentos alineada con la soberanía alimentaria.

PALABRAS CLAVE: tratado internacional, comercio, derecho a la alimentación, economía del mercado, agricultura.

\section{INTRODUCTION}

Ecuador ratified the FTA with the European Union in December 2016, and its biding effects started since January 2017. Since then, almost four years have passed, and Ecuador is currently dealing with one of the worst social, economic and sanitary crises, mainly generated by COVID-19 pandemic and the massive plunge in oil prices. In this context, it is necessary to reevaluate the situation of food sovereignty in Ecuador and the economic and commercial effects of the FTA with the European Union with an economic analysis of law perspective. Considering the vital importance that a sustainable food production system will have in the following years, not only to avoid hunger in ascendant poverty and unemployment landscape but also to strengthen the countryside and the local production as a source of sustainable development.

Consequently, the present article evaluates the situation of food sovereignty in Ecuador as an ongoing project which implementation has faced massive delays, and until today is not a reality. Then, it explains the relationship between 
food sovereignty and the most relevant FTA's biding provisions regarding agriculture and sustainable development, to finally expose a brief analysis, from the economic analysis of law, of some implications that the FTA presents about the Ecuadorian food sovereignty regime.

\section{FOOD SOVEREIGNTY: AN INCOMPLETE PROMISE IN ECUADOR}

The COVID-19 economic and sanitary crisis has shown that the world's food system is extremely fragile and that the traditional discourse of "food security" is not enough to undertake the pressing worldwide hunger and poverty problems. Additionally, the pandemic has proven that the agroindustrial production methods, controlled by a small group of international corporations, is failing. Nowadays, more than ever, we are conscious of the importance of the countryside and local production, because we can live without cars, planes or clothes, but yes, we cannot live without food.

According to the "2020 Global Report on Food Crises", in 2019, 135 million people were suffering from acute hunger. This number "increased by 22 million between 2018 and 2019, as a result of worsening acute food insecurity conditions" (World Food Programme, 2020, p. 20), and "the COVID-19 pandemic could now double that number, putting an additional 130 million people at risk of suffering acute hunger by the end of 2020" (United Nations, 2020).

In Latin America, the situation is similar. Because of the pandemic, the population in conditions of extreme poverty could reach 83.4 million people in 2020 , which would imply a significant rise in the levels of hunger (ECLAC, 2020). For this reason, the implementation of adequate food policy in Ecuador, oriented towards food sovereignty, should be a priority for the government.

In general terms, the concept of food sovereignty was developed by a transnational social movement, mainly integrated by producers, called "Vía Campesina" in 1996 
(Bellinger \& Fakhri, 2013). The main objective was to create a new collaborative and sustainable food production system. Also, reflecting other relevant dimensions not considered by the traditional concept of "food security", understand as the situation in which "all people, at all times, have physical and economic access to sufficient, safe and nutritious food to meet their dietary needs and food preferences for an active and healthy life. In this regard, concerted action at all levels is required" (FAO, 1996). In this way, during the Nyéléni Forum of 2007 , the "food sovereignty" was defined as:

(...) the right of peoples to healthy and culturally appropriate food produced through ecologically sound and sustainable methods, and their right to define their food and agriculture systems. It puts the aspirations and needs of those who produce, distribute and consume food at the heart of food systems and policies rather than the demands of markets and corporations. It defends the interests and inclusion of the next generation. It offers a strategy to resist and dismantle the current corporate trade and food regime, and directions for food, farming, pastoral and fisheries systems determined by local producers and users. Food sovereignty prioritizes local and national economies and markets and empowers peasant and family farmerdriven agriculture, artisanal - fishing, pastoralistled grazing, and food production, distribution and consumption based on environmental, social and economic sustainability. Food sovereignty promotes transparent trade that guarantees just incomes to all peoples as well as the rights of consumers to control their food and nutrition. It ensures that the rights to use and manage lands, territories, waters, seeds, livestock and biodiversity are in the hands of those of us who produce food. Food sovereignty implies new social relations free of oppression and inequality between men and women, peoples, racial groups, social and economic classes and generations. (Declaration of Nyéléni, 2007) 
It is important to mention that the fight for food sovereignty has a significant impact on the conception of peasant's rights and food policy worldwide. Thus, at the end of 2018, the UN General Assembly adopted the United Nations Declaration on the Rights of Peasants and Other People Working in Rural Areas. It recognizes food sovereignty as a right ${ }^{2}$, for the first time (United Nations, 2018). While this international instrument does not generate binding effects, it is an important precedent for the development of food sovereignty at the international level. (Paredes, 2019)

Now, regarding Ecuador, in 2008, the Article 281 of the Ecuadorian Constitution included "food sovereignty" as a strategic objective and a State obligation to ensure that individuals and communities achieve self-sufficiency of healthy and culturally appropriate food permanently (CRE, 2008). Although it was not directly stated as a "right", the Constitution considers specific responsibilities that the State should follow to fulfil the food sovereignty objectives. For instance, adopt fiscal and tariff policies to protect the national agri-food sector (CRE, 2008, Art. 281.2), and promote the food system transformation. (CRE, 2008, Art. 281.1)

Additionally, the food sovereignty principles were included in the National Development Plan 2017-2021, which contains the foundations for the State's public policy framework. As part of this plan, objective number 6 for the national development, refers to "develop productive and environmental capacities to achieve food sovereignty and rural Good Living" (SENPLADES, 2017). Furthermore, the Ecuadorian Legislative Body enacted the Food Sovereignty Law in 2009.

Nevertheless, more than ten years have passed, and the food sovereignty regime is still an inconclusive promise. Mainly because of the reduced budget of the Plurinational

2 The Article 15.4 states: "Peasants and other people working in rural areas have the right to determine their food and agriculture systems, recognized by many States and regions as the right to food sovereignty. It includes the right to participate in decision-making processes on food and agriculture policy and the right to healthy and adequate food produced through ecologically sound and sustainable methods that respect their cultures" (United Nations, 2020) 
and Intercultural Conference on Food Sovereignty (COPISA); the only institution responsible of the formulation of food sovereignty policies, and, the inexistent secondary regulation that could turn applicable the dispositions contained in the Food Sovereignty Law. Ecuador has not advanced in the adoption of a new model of food production; contrary, it has deepened the traditional agro-industrial practices. (Paredes, 2019)

\section{THE FREE TRADE AGREEMENT WITH THE EUROPEAN UNION AND FOOD SOVEREIGNTY}

The Free Trade Agreement between Ecuador, Colombia Peru and the European Union (FTA) entered into force in 2017. This international instrument aims to "establish a free trade area, in conformity with Article XXIV of the General Agreement on Tariffs and Trade of 1994 (...) and Article V of the General Agreement on Trade in Services" (FTA, 2016, Art. 3) and includes: (i) the Protocol of Accession to the Trade Agreement between the European Union and its member states, on the one hand, and Colombia and Peru, on the other, to consider Ecuador's accession; (ii) the annexes to this Protocol; and, (iii) the Trade Agreement between the European Union and its Member States, of the one part, and Colombia and Peru, of the other part. (Opinion No. 009-16-DTI-CC, 2016, p.24; Paredes, 2019)

It is essential to mention that all the provisions of the FTA are binding for the country as provided for in Article 8 of this international instrument. Also, the State shall take "any necessary measure to implement the obligations under it, including its observance by central, regional or local governments and authorities" (FTA, 2016, Art. 8.1). Otherwise, the State would breach the Agreement and should submit to the Dispute Settlement Mechanism set out in Title XII of the FTA.

The FTA includes some provisions about human rights and agriculture, which are strictly related to food sovereignty regime in Ecuador. The Article 1 states that the principles of human rights and democratic development are the basis of the Agreement, while the Article 4.a states that one of the 
objectives of the instrument is to create a "progressive and gradual liberalization of trade in goods, in conformity with Article XXIV of the GATT 1994". Besides, Article 5 of FTA establishes that the Parties reaffirm the rights and obligations acquired under the WTO Agreement, including the principle of National Treatment, defined as follows:

(...) national treatment shall mean, concerning any level of government or authority, treatment no less favourable than the treatment accorded by that level of government or authority to like, directly competitive or substitutable domestic goods, including those originating in the territory over which that level of government or authority exercises jurisdiction. (FTA, 2016, Art.21.2)

This principle was already in force since 1996 when Ecuador became part of the WTO, but its effect has multiplied in combination with tariff elimination of agricultural products (Paredes, 2019). Nevertheless, the FTA has excluded some sensible Ecuadorian products of this tariff elimination and has introduced a quota of metric tons with zero tariffs in products like milk. (FTA, 2016, Annex IV.7)

Regarding agriculture, the FTA creates the Subcommittee on Agriculture and includes the Section Fourth of Title III called "Agricultural Goods", specifically dedicated to regulating the options that subscriber countries would have to mitigate the potential impacts that tariff elimination might have on domestic food production. (FTA, 2016, Art.36)

One of the most relevant options is the possibility of applying an "agricultural safeguard" ${ }^{3}$ Measure in the form of

3 According to Article XIX of the GATT 1994 (General Agreement on Tariffs and Trade). A safeguard is a measure of urgency that can be implemented if, as a result of tariff concessions provided to the parties "imports of a product into the territory of this contracting party have increased by such quantity and are carried out under such conditions as to cause or threaten to cause serious injury to domestic producers of like products or directly competitive in that contracting party" (GATT, 1994). Then, the safeguards are intended to "prevent or remedy such damage, to suspend in whole or 
additional import duties on originating agricultural goods" (FTA, 2016, Art.29). However, Ecuador should meet the following conditions:

1. The product should be included in the list of Annex VII "Covered goods and activation import volumes" of the FTA. Thus, the products to which an agricultural safeguard could be applied would be onions and shallots; some varieties of beans and dairy products (FTA, 2016, Annex VII. 1 and 2), provided that the amount of imports per year of these products exceeds a certain amount of tons set out in Annex VII of FTA. (FTA, 2016, Art.29.2)

2. The tariff added to the good as a safeguard measure cannot exceed the regular tariff charged to all other countries that are not part of the Agreement, but of the WTO (Most Favored Nation tariff). (FTA, 2016, Art.29.1)

3. This safeguard may not be adopted if the State has other types of safeguards, on the same good, in force. (FTA, 2016, Art.29.4)

4. No Party may adopt or maintain an agricultural safeguard measure from the date a good is duty-free. (FTA, 2016, Art.29.5.a)

5. The party applying an agricultural safeguard shall notify the exporting party in writing, within ten days, justifying the reasons for the measure. The exporting party shall have the opportunity to consult whether or not the application of the measure is relevant, and may activate the dispute settlement mechanism if it does not agree. (FTA, 2016, Art.29.6) 
Consequently, one of the most relevant mechanisms to control the entrance of foreign products that may affect domestic production, and thereby food sovereignty, is the possibility of adopting an agricultural safeguard. However, there is the need to fulfil all the requisites mentioned above, and the safeguard cannot be applied to any agri-food goods that may be threatened. Only could be applied to " 13 products, such as mature and semi-mature cheeses (humidity up to 63.5\%) and peasant economy products such as onions and beans". (MCE, 2016, p. 1)

There are other options that the FTA presents in order to mitigate the adverse effects of this instrument in the local agricultural production, like the possibility to apply the Andean System of Agricultural Price Strips established in Decision 371 of the Andean Community of Nations (FTA, 2016, Art. 30) or the Technical Assistance to strength the Trade Capacities. (FTA, 2016, Art. 100)

However, it is necessary to consider that Free Trade Agreements and food sovereignty have different objectives. The first response to an exogenous development theory ${ }^{4}$, While the second strongly supports an endogenous development theory ${ }^{5}$ (Paredes, 2019). Additionally, according to Peter Halewood (2011):

Trade liberalization can have detrimental effects on the long term food security of less developed countries. This includes the environmental damage that may result from a country's attempt to satisfy export demand. Rather than working under environmentally friendly standards or sustainability models for agriculture, forestry or fish stocks, many countries

4 According to Lee \& Gimm (2009): "the approach considers the organizational structures of global firms' production systems as the determinants of growth and explores how nations are transformed by flows of capital, labour, and knowledge all of which are regarded as external factors" (p. 614)

$5 \quad$ According to Van der Ploeg \& Long (1994): "endogenous development practices tend to materialize as self-centred processes of growth: that is, relatively large parts of the total value generated through this type of development are re-allocated in the locality itself". (p. 2) 
are forced to grapple with the global demand for these goods (...) Trade liberalization often has the distorting effect of shifting the limited amount of resources a less developed country may have from production geared towards local consumption to production for export to the global market. While the net benefit of producing goods for export may be high, it comes at a steep price for many people in developing countries. (pp. 126-228)

In this context, in Ecuador, after almost four years of its entry into force, the FTA has generated a wide range of effects. The most perceptible have been the ones associated with the Ecuadorian balance of payments. Thus, non-oil exports have growth of 540.7 million US dollars comparing the period January-April of 2018 and 2020. On the other hand, non-oil imports, in the same period, have to decrease 863.7 million US dollars. This tendency has been deeply influenced by the COVID-19 worldwide crisis and the recent plunge in oil prices (Banco Central del Ecuador, 2020). Moreover, in 2020 it is expected a reduction of EU international commerce in $9.2 \%$ of exports and $8.8 \%$ of imports. (Stearns, 2020)

Additionally, comparing the periods January-April 2018 and 2020, we should notice that the significant exports growth has focused in traditional goods, like banana, shrimps or cocoa, while non-traditional exports have grown only 93 million US dollar. It could mean that the FTA has not helped the State to diversify its production. (Banco Central del Ecuador, 2020)

As we can see, the effects and implications of the FTA in the Ecuadorian food sovereignty regime are even more challenging to assess in the current sanitary and worldwide economic crisis. Nevertheless, to contribute to further studies on the subject, in the next section, we will briefly analyze the relationship between the FTA and food sovereignty under an economic analysis of law perspective. 


\section{FTA AND FOOD SOVEREIGNTY: AN ANALYSIS FROM THE ECONOMIC ANALYSIS OF LAW}

It is essential to establish that the Economic Analysis of Law (EAL) has descriptive, heuristic and normative aspects. According to Richard Posner (2009):

As a heuristic, it seeks to display underlying unities in legal doctrines and institutions; in its descriptive mode, it seeks to identify the economic logic and effects of doctrines and institutions and the economic causes of legal change; and in its normative aspect, it advises judges and other policymakers on the most efficient methods of regulating conduct through the law. (p. 38)

In this sense, the Economic Analysis of Law aims to link critical economic concepts, such as efficiency, transaction costs and opportunity costs, with the different scenarios of legal and social application, contributing to the deep understanding of the structures underlying different legal realities, and; therefore, to the better construction of public policies and regulatory instruments.

It makes sense if we consider that law and market use prices as opportunity costs ${ }^{6}$ That induce people to efficient maximization (Monroy, 2018, p. 713). Thus, for example, the legal system sets out the costs of people's acts, which can decide to do a particular action (regulatory hypotheses), knowing they will bear the costs that it entails (legal consequences). Likewise, Posner (1987) explains that the economic analysis of law has two basic premises:

1) People act as rational maximizers of their satisfaction in making such nonmarket decisions as to whether to marry or divorce, commit or refrain from committing

$6 \quad$ Also called alternative cost, it expresses the primary relationship between scarcity and choice. Opportunity cost is the anticipated value of "what would have been" if the choice made under a given circumstance would have been different. Therefore, in an environment where there is no shortage, there are no opportunities or alternatives to be sacrificed. (Buchanan, 1991, p. 520) 
crimes, make an arrest, litigate or settle a lawsuit, drive a car carefully or carelessly, pollute (a nonmarket activity because pollution is not traded in the market), refuse to associate with people of a different race, fix a mandatory retirement age for employees.

2) Rules of law operate to impose prices on (sometimes subsidize) these nonmarket activities, thereby altering the amount or character of the activity (p. 5)

We can also appreciate opportunity and transaction costs $^{7}$ when we refer to the construction of the national regulatory system and the incorporation of binding international instruments into the current legal order, such as the FTA.

In economic terms, the FTA is a contract that could be defined as "the specification of actions that are supposed to be adopted by designated parties at various times, usually depending on the conditions governing the contract" (Shavell, 2004, p. 327). This kind of international instruments results from non-monetized transactions between States, whose purpose is not the exchange of goods or services, but rather the exchange of their jurisdiction, sovereignty or regulatory authority. (Monroy, 2018, p. 734)

In this sense, international transactions are often better understood as agreements in which States coordinate their actions, intending to lower transaction costs, allocating risks and acting efficiently ${ }^{8}$. In the particular case of the FTA,

7 are those "costs and expenses related to the activities carried out by a company to: acquire market information, draft contracts, conduct inspections, agree on disputes, cover contingencies, force compliance with legal and contractual rules (enforcement) and comply with health and tax provisions; to identify, negotiate and consummate an economic transaction. In broader terms, the "Direct Cost", ex-ante and ex-post, arising as a result of the completion of a commercial operation" (Silva, 2003, p. 11). According to Monroy (2018), in the context of international law, they are understood as the "costs associated with specifying and enforcing agreements". (p. 731)

8 Concerning the motivations for entering into international agreements such as the FTA, Shavell (2004) mentions the following: (i) provision of goods and services in the future. It often happens that one of the parties 
the coordination between parties took place to establish an exchange relationship, not a cooperation relationship, as the parties gave up part of their sovereignty to establish a free trade area, negotiate tariff reductions and accept legislative limitations or adaptations, in order to obtain certain benefits.

In order to briefly assess whether the FTA has allowed the State to reduce transaction costs ${ }^{9}$ Regarding food trade in the context of food sovereignty, it is necessary to consider these four fundamental factors proposed by Douglass North (1992): (i) the cost of measuring the valuable attributes of goods or services or the performance of agents in the exchange, related to the amount of information that the parties possess, which can help one benefit more than the other; (ii) the size of the market, which determines a personal or impersonal exchange; (iii) the contracts enforcement capacity; and, (iv) the existence of strong institutions to reduce the costs of measuring and enforcement of contracts, avoiding the taking of individual ideological perceptions and attitudes as parameters.

Regarding the first factor, the asymmetry between the FTA's subscriber parties regarding its economic, institutional and political conditions may make one more likely to know and measure the implications of the FTA (Janvry \& Sadoulet, 1997). For instance, within the initial assessments of the costs of ratifying the FTA, the Ecuadorian State should have given primacy to the evaluation of the impacts on negotiated rights: a) the right to food; b) to a healthy environment; and, c) to sovereignty, which includes the dimension of food sovereignty.

will want to enjoy a good or service in the future and that the other party may provide such good or service, resulting in the fact that the desire to celebrate the contract is mutual (p. 332); (ii) Mutually beneficial risksharing (p. 333); (iii) guaranteed markets.

9 It is important to mention that transaction costs are expressed. Differently, ex-ante may refer to negotiation costs; ex-post can refer to realignment costs or renegotiation costs when agents make bilateral efforts to correct misalignments; the costs of establishing and managing a dispute resolution structure (which is not necessarily a court); and the costs of securing the commitments. (Monroy, 2018, p. 732) 
However, because these measurements are quite costly, there is no evidence of pre-ratification governmental studies on the impacts of the FTA in these aspects. Also, if they would have existed, they would not have been useful, since Ecuador did not have the opportunity to widely negotiate its terms, adhering to the Agreement previously concluded with Colombia and Peru.

Referring to the size of the market, the commercial exchange generated between Ecuador and the European Union under the FTA is impersonal, representing higher costs to ensure the enforcement of the treaty (North, 1992). It is essential to mention that the FTA establishes transparent institutions (rules of the game) about the trade of agri-food goods, including tariff elimination annexes and the description of the processes to be carried out in the event of non-compliance.

However, there are no well-defined mandatory procedures for enforcing rules about trade and sustainable development (related to food sovereignty). Thus, the FTA only includes good-faith statements and reaffirms the parties' responsibility of respecting international conventions on adequate work or environmental care (FTA, 2016, Title IX Trade and Sustainable Development). This situation, in the context of an impersonal trade, could lead to opportunistic behaviours.

Therefore, to ensure that free trade in agricultural goods meets the objectives of food sovereignty, sustainable production and respect for human rights - established in the Constitution of the Republic- Ecuador must incur in high costs. They are considering that judicial institutions, for example, are not prepared for the adequate protection of food sovereignty. Not even the Constitutional Court, Ecuador's main constitutional justice body, conducted an adequate analysis of the possible impacts of the FTA on food sovereignty before its ratification. (Opinion No. 009-16-DTI-CC, 2016) 
Regarding the fourth factor for assessing transaction costs, Ecuador does not present institutional or organizational strength $^{10}$ (loud and stable entities responsible for compliance with the rules of the game) to reduce the costs of measuring and enforcing the FTA's provisions related to sustainable development and agri-food trade, since there is no uniform agricultural and commercial, public policy that favours food sovereignty over agribusiness (Cherrez \& Herrera, 2016). With this institutional weakness, it is costly for the State to observe the FTA's provisions while ensuring compliance with the legal regime of food sovereignty.

Hence, the FTA fails to reduce transaction costs if we evaluate the agri-food trade from a food sovereignty approach (and we should consider that food sovereignty is a strategic objective and a State obligation), but it does reduce those costs if we look at food trade from a free-market perspective that favours agribusiness. On the other hand, it is essential to mention that the lack of compliance with food sovereignty regime is not new, and has not started because of the ratification of the FTA, although this international instrument has reduced the State's capacity to act in this area. (Janvry \& Sadoulet, 1997)

However, the study of transaction costs is directly related to the estimation of the efficiency ${ }^{11}$ of a particular contract, or in this case, of an international treaty (Ferro, Lentini \& Romero, 2011). There are two main types of efficiency, technical and allocative. Technical efficiency is traditionally understood as "obtaining as much product as possible, from a given set of inputs" (Ferro et al., 2011, p. 9), i.e. implies a profit maximization.

10 Thus, in a brief period, the regulations and public institutions which govern the issues of foreign trade, agriculture, fisheries, environment, water and land have presented changes in their structural organization, name and category (DE- 533, 2018; DE-559, 2018). It shows that there is no stability in terms of the normative or political organization regarding aspects of food sovereignty.

11 When we talk about efficiency, in general, we are referring to economic or total efficiency, which is shaped by the union of technical efficiency (maximizing benefits) and allocative efficiency (cost minimization) 
This concept implicitly entails the fact that there are scarce resources that must be used to make the most of their potential. Thus, in the case of trade agreements, states should aim to generate the most significant amount of satisfaction of their population needs, based on the specific circumstances and resources (economic and political) that they have. (Ferro et al., 2011)

Related to agri-food trade guided by a food sovereignty logic, the FTA would not generate technical efficiency, because it does not allow the local Ecuadorian food producers to maximize their profit with fewer production resources. Instead, it involves additional costs because peasants must invest more to compete with the massive inflow of European agricultural products. (Ferro et al., 2011)

A different circumstance is observed regarding largescale agricultural producers, for which the FTA generates technical efficiency because they can produce and export more products at lower costs, considering that chemical inputs, for example, are imported from the EU at lower prices, thanks to the tariff reduction agreed in the FTA.

Thus, it means that the FTA does not allow the maximization of small producers well-being, and instead generates poverty growth and rural marginalization; however, it does allow the maximization of extensive agribusinesses wellbeing that have the most significant tariff and trade advantages for export.

Regarding allocative efficiency, understood as the obtention of a product at the lowest possible cost by performing an efficient reallocation of productive resources, we can mention that the FTA is efficient, if we evaluate food trade in general, because it allows to minimize production costs and increase exportations with the corresponding increase in profits. However, if we assess food trade from a food sovereignty perspective, which should be done by constitutional provision, the FTA does not represent allocative efficiency, because it increases the costs of agroecological and sustainable production. 
It can create several adverse effects, for example, worse working conditions in the countryside, or pollution from excessive use of chemical inputs, resulting in more expensive for the country over time. Consistent with the above, Janvry \& Sadoulet (1997) state that any globalizing process as the FTA, mainly involves two negative welfare consequences:

One is the creation of transitory poverty associated with the redefinition of economic activity, such as loss of a job, falling profitability of activities exposed to international competition, and in thegeneral devaluation of the factors that were scarce in each economy before trade opening. These effects can be attended through compensatory programs (...) complemented by general safety nets such as food subsidies and unemployment insurance. The other type, which is more difficult to handle, is the exclusionary effect of globalization whereby many households and communities that were poor before [FTA] will remain marginalized from the process, and thus with increasingly distant welfare levels compared to those who capture the gains from globalization. (p. 15)

In this sense, free trade agreements such as the FTA generate polarization between those who benefit (agribusiness) and those who are harmed (small producers) by trade liberalization measures. In this regard, Calabresi \& Melamed (1972) state that in these cases, the State must decide which party to favour and, therefore, establishes through legal institutions (rules of the game). Therefore, the different "entitlements"12.

12 About entitlements, Calabresi \& Malamed (1972) mention: "Whenever a state is presented with the conflicting interests of two or more people or two or more groups of people, it must decide which side to favour. Absent such a decision, access to goods, services, and life itself will be decided based on "might makes right" - whoever is more robust or shrewder will win. 3 Hence the fundamental thing that law does is to decide which of the conflicting parties will be entitled to prevail. The entitlement to make noise versus the entitlement to have silence, the entitlement to pollute versus the entitlement to breathe clean air, the entitlement to have children versus the entitlement to forbid them these are the first order of legal decisions". (p. 1090) 
Thus, if we consider that the entitlement in the conflict was the ratification or not of the FTA, the State had to analyze indepth the three main reasons for granting entitlement, namely "economic efficiency, distributional preferences and other justice considerations" (Calabresi \& Melamed, 1972, p. 1093). Economic efficiency implies that, in the presence of different transaction costs, the State must decide on the entitlement that reports lower costs.

Consequently, before ratifying the FTA, the Ecuadorian government should have assessed the benefits it would bring, the social costs of obtaining those benefits, and the social costs of avoiding or remedying negative costs. However, this was not done in-depth, nor it was noted that “(...)in the absence of certainty as to whether a benefit is worth its costs to society, that the cost should be put on the party or activity (...) which can with the lowest transaction costs act in the market to correct an error in entitlements". (Calabresi \& Melamed, 1972, p. 1097)

In this context, the ratification of the FTA was not an efficient decision to promote the exchange of agricultural goods guaranteeing food sovereignty, mainly because the social costs in the countryside are higher than the benefits that the FTA brings to small producers. Moreover, we say that it is not efficient, because the cost of the Agreement is placed on the poorest (small agricultural producers), that is, on those who are less prepared to deal with them.

There are also distributional objectives that underpin the State's choice of some entitlements. In all societies, we find different preferences in the distribution of wealth, such as class preferences or greater social equality. In the case of Ecuador, for example, article 3 of the Constitution establishes as the primary duty of the State: "to plan the national development, eradicate poverty, promote sustainable development, and equitable redistribution of resources and wealth, in order to access good living”. (CRE, 2008) 
In this context, the State should choose the entitlement that is considered the most favourable to general well-being and equity objectives. Therefore, the correct choice, in distributional terms, might have been the non-ratification of the FTA, although many other factors influenced this decision (Calabresi \& Melamed, 1972).

In addition to efficiency and distributional objectives, there are other reasons for justice to opt for a particular entitlement (in this case, the different entitlement is whether or not to ratify the FTA). However, it is quite complex to analyze a particular state election in this regard, as some consider that "what sounds like a justice standard is simply a handy way of importing efficiency and distributional notions too diverse and general in their effect to be analyzed fully in the decision of a specific case". (Calabresi \& Melamed, 1972, p. 1103)

However, there are three types of entitlements:

The entitlement protected by property rules, in the sense that "someone who wishes to remove the entitlement from its holder must buy it from him in a voluntary transaction in which the value of the entitlement is agreed upon by the seller”. (Calabresi \& Melamed, 1972, p. 1092)

Those protected by liability rules presented when "someone may destroy the initial entitlement if he is willing to pay an objectively determined value for it". (Calabresi \& Melamed, 1972, p. 1092)

Those protected by inalienability rules, or basic entitlements, whose transfer is not permitted.

The rules of inalienability "not only protect but can also be seen as limiting or regulating the granting of entitlements itself". (Calabresi \& Melamed, 1972, p. 1111)

The ratification of the FTA represents a case in which economic efficiency on agricultural goods trade is caused by the limitations imposed to the State by the Agreement, especially in 
terms of food sovereignty. It generates significant externalities (Calabresi \& Melamed, 1972), which may justify the application of an inalienability rule, mainly when external costs

(...) do not lend themselves to standard measurement, which is acceptably objective and non-arbitrary. This non-monetizability is characteristic of one category of external costs which, as a practical matter, frequently seems to lead us to rules of inalienability. Such external costs are often called moralisms”. (Calabresi \& Melamed, 1972, p. 1112)

\section{CONCLUSION}

In Ecuador, the implementation of food sovereignty as a sustainable food production system that leads to local production improvement and respect to human rights, is -and certainly will be for a while- an incomplete promise. Although the Ecuadorian Constitution recognizes it as a strategic objective and a State obligation, there are not enough enforcing mechanism to avoid, for example, the adoption of international instruments that are not aligned with its objectives. It is the case of the FTA, which have generated high costs regarding the food sovereignty regime compliance, and negative externalities for domestic agricultural production. All of this may suggest the importance of applying an inalienability rule to avoid the mentioned external costs, by renegotiating the FTA and adopting new strategies to strengthen the Ecuadorian countryside. 


\section{REFERENCES}

Banco Central del Ecuador. (2020). Evolución de la Balanza Comercial. Enero -Abril 2020. Quito: Subgerencia de Programación y Regulación Dirección Nacional de Síntesis Macroeconómica. Retrieved from https:// contenido.bce.fin.ec/documentos/Estadisticas/ SectorExterno/BalanzaPagos/balanzaComercial/ ebc202006.pdf

Bellinger, N., \& Fakhri, M. (2013). The Intersection Between Food Sovereignty and Law. Natural Resources \& Environment, (pp. 45-48).

Buchanan, J. (1991). Opportunity Cost. In: Eatwell J., Milgate M., Newman P. (eds). The World of Economics. (pp. 520-525). London: Palgrave Macmillan.

Calabresi, G., \& Malamed, D. (1972). Property Rules, Liability Rules, and Inalienability: One View of the Cathedral. Harvard Law Review, 85(6), (pp. 1089-1128).

Constitution of the Republic of Ecuador. (2008). [Const.]. Oficial Diary 449, October, 20. 2008.

Ecuadorian Constitutional Court. (2016). Opinion No. 009-16-DTI-CC. Retrieved from: http://portal. corteconstitucional.gob.ec/Raiz/2016/009-16-DTICC/REL_SENTENCIA_009-16-DTI-CC.pdf

Cherrez, C., y Herrera, J. (November 15, 2016). El Gobierno pasará a la historia por una de las campañas de engaño más fuertes para el Ecuador con el acuerdo con la Unión Europea. (Ecuador Inmediato, Interviewer) 
Declaration of Nyéléni. (2007). Forum for Food Sovereignty, Nyéléni 2007. Nyéléni. Retrieved from: https://nyeleni. org/spip.php?article290

ECLAC. (2020, 16 June). FAO and ECLAC: Millions of People May Slide into Extreme Poverty and Hunger in 2020 in Latin America and the Caribbean due to the Pandemic's Impact. Press Release. Retrieved from: https://www. cepal.org/en/pressreleases/fao-and-eclac-millionspeople-may-slide-extreme-poverty-and-hunger-2020latin-america

FAO. (1996). World Food Summit. Rome. Retrieved from: http:// www.fao.org/3/w3613e/w3613e00.htm

Ferro, G., Lentini, E. \& Romero, C. (2011). Eficiencia y su medición en prestadores de servicios de agua potable $y$ alcantarillado. CEPAL - Colección Documentos de proyectos. Retrieved form: https://archivo.cepal.org/ pdfs/Waterguide/lcw0385s.PDF

Halewood, P. (2011). Trade Liberalization and Obstacles to Food Security: Toward a Sustainable Food Sovereignty. The University of Miami Inter-American Law Review, 43(1), (pp. 115-136).

Janvry, A. y Sadoulet, E. (1997). NAFTA and Agriculture: An Early Assessment, 57 (221), (pp. 13-60). Retrieved from: https://ideas.repec.org/p/ags/ucbecw/25089.html

Lee, Y.-S., \& Gimm, D.-W. (2009). Endogenous versus exogenous development: a comparative study of biotechnology industry cluster policies in South Korea and Singapore. Environment and Planning C: Government and Policy, 27, (pp. 612-631). 
MCE. (2016). Situación del sector de lácteos en el Acuerdo Comercial Multipartes con la UE. Retrieved from: https://www.comercioexterior.gob.ec/wp-content/ uploads/downloads/2016/11/Documento-lecheACM_completo.pdf

Monroy, D. (2018). Una aproximación neoinstitucionalista al derecho (económico) internacional. Reflexiones Jurídicas, 4, (pp. 709-761).

Moreno, L. (October 03, 2018). Decreto Ejecutivo No. 533. RO: Suplemento 360

Moreno, L. (November 14, 2018). Decreto Ejecutivo No. 559. RO: Suplemento 387

North, D. (1992). Transaction Costs, Institutions, and Economic Performance. San Francisco: International Center for Economic Growth.

Paredes, A. (2019). Free Trade Agreement with the European Union: An analysis from the legal system of food sovereignty in Ecuador. Revista de la Facultad de Jurisprudencia-PUCE, (pp. 97-116).

Paredes, A. (2019). Régimen Jurídico Ecuatoriano de Soberanía Alimentaria: Efectos del Acuerdo Comercial con la Unión Europea. Quito: Corporación de Estudios y Publicaciones.

Posner, R. (1987). The Law and Economics Movement. The American Economic Review (pp. 1-13).

Posner, R. (2009). Law and Economics in Common-Law, Civil-Law, and Developing Nations. Revista de Estudos Constitucionais, Hermenêutica e Teoria do Direito (RECHTD), (pp. 37-45). 
The programme, W. F. (2020). 2020 - Global Report on Food Crises. Rome: Global Network Against Food Crisis.

Protocolo de Adhesión del Acuerdo Comercial entre la Unión Europea y sus Estados miembros, por una parte, y Colombia y el Perú, por otra, para tener en cuenta la Adhesión de Ecuador. (2016). RO: Edición Especial 807.

SENPLADES. (2017). Plan Nacional de Desarrollo 2017-2021. Ecuador. Retrieved from: https://www.planificacion. gob.ec/wp-content/uploads/downloads/2017/10/ PNBV-26-OCT-FINAL_0K.compressed1.pdf

Shavell, S. (2004). Fundamentos del análisis económico del Derecho. Madrid: Editorial Centro de Estudios Ramón Arces.

Silva, A. (2003). Los Costos de Transacción Origen, Aplicación y Definición del Concepto. Retrieved from: https:// www.researchgate.net/publication/263929850_ Los_Costos_de_Transaccion_Origen_Aplicacion_y_ Definicion_del_Concepto?enrichId=rgreq384ce4eb9867ccf5f7e33a9872b2b52c-XXX\&enrichS ource=Y292ZXJQYWdlOzI2MzkyOTg1MDtBUzoxM Tk0NTcwNDEwOTY3MDRAMTQwNTQ5MjE4NjM5 MA\%3D\%3D\&el=1_x_3\&_esc=publicationCoverPdf

Stearns, J. (2020, april 19). El comercio exterior de la UE caería en US\$ 570 mil millones en 2020. Pauta. Retrieved from: https://www.pauta.cl/economia/bloomberg/ el-comercio-exterior-de-la-ue-caeria-en-us-570-milmillones-en-2020

Trade Agreement between the European Union and its Member States, of the one part, and Colombia and Peru, of the other part. (2016). Retrieved from: http://publications. europa.eu/resource/cellar/42e02e6c-1698-465e923c-d2d12f91c728.0017.04/DOC_1 
United Nations. (2018, 28 September). United Nations Declaration on the Rights of Peasants and Other People Working in Rural Areas. Resolution adopted by the Human Rights Council on 28 September 2018(A/ HRC/RES/39/12). Retrieved from file://C:/ Users/PAREDE 1/AppData/Local/Temp/A_HRC_ RES_39_12-EN.pdf

United Nations. (2020, 07 July). Sustainable Development Goals. Retrieved from: https://www.un.org/ sustainabledevelopment/hunger/

Van der Ploeg, J., \& Long, A. (1994). BORN FROM WITHIN. Practice and Perspectives of Endogenous Rural Development. Hague: Van Gorcum.

World Trade Organization. (1994). General Agreement on Tariffs and Trade (GATT 1994).

Received: 27/07/2020

Approved: 31/07/2020

Antonella Paredes Torres: Lawyer and member of the "Research Group on Economic Law, Institutional Competitiveness, Innovation, Development, Jurimetrics and Public Policy" at the Pontificia Universidad Católica del Ecuador. Founding partner of the Law Firm "Paredes Abogados y Consultores". Attorney at the Ecuadorian Attorney's General

Emails: antonella.paredes@pge.gob.ec antop24@hotmail.com

City: Quito

Country: Ecuador 
